Article

\title{
Liminal and Transmodern Female Voices at War: Resistant and Healing Female Bonds in Libby Cone's War on the Margins (2008)
}

\author{
Silvia Pellicer-Ortín (D) \\ Department of English and German Philology, Faculty of Education, University of \\ Zaragoza, C/Pedro Cerbuna, 12, 50009 Zaragoza, Spain; spellice@unizar.es
}

Received: 30 June 2018; Accepted: 6 November 2018; Published: 14 November 2018

\begin{abstract}
When addressing marginal experiences during the Second World War, the German occupation of the Channel Islands deserves pride of place, as very few writers have represented that liminal side of the conflict. One of these few writers is Libby Cone, who published War on the Margins in 2008, a historical novel set on Jersey during this occupation and whose main protagonist encounters various female characters resisting the occupation from a variety of marginal positions. Drawing from Rodríguez Magda's distinction between "narratives of celebration" and "narratives of the limit", the main claim behind this article is that liminality is a general recourse in transmodern fiction, but in Cone's War on the Margins it also acts as a fruitful strategy to represent female bonds as promoters of empathy, resilience and resistance. First, this study will demonstrate how liminality works at a variety of levels and it will identify some of the specific features characterizing transmodern war narratives. Then, the female bonds represented will be examined to prove that War on the Margins relies on female solidarity when it comes to finding resilient attitudes to confront war. Finally, this article will elaborate on how Cone uses these liminal features to voice the difficult experiences that Jewish and non-Jewish women endured during the Second World War, echoing similar conflictive situations of other women in our transmodern era.
\end{abstract}

Keywords: liminality; Second World War; the Channel Islands; feminism; love; resilience; empathy; women's historical fiction; transmodern; Libby Cone

\section{Introduction: History, War, and Fiction in the Transmodern Context}

The upsurge of Postmodernism and New Historicism brought to the fore the debate about the boundaries between literary and historical discourses, refusing the view that "only history has a truth claim" and demonstrating that "both history and fiction are discourses" [1] (p. 93). In keeping with this, Lyotard's defense of the power of petit récits against the hegemonic grands récits of history [2] can still be traced in abundant contemporary historical novels offering alternative versions of some of the darkest episodes of our recent history. The increasing interest in the "new histories" of women, non-Western cultures, and ethnic, racial, and sexual minorities since the late 1960s [3] (p. 3) also explains why many literary works about the Second World War written by women have provided alternative sites where unheard "counterstories" [4] of war and survival can be voiced, demonstrating that "what matters most in history is often experienced on its margins" [5] (p. 144). Moving onto the present-day literary panorama, several critics claim that contemporary Anglophone fiction has recently taken "a historical turn" in which the historical novel has "flourished" and "undergone energetic feminist and postcolonial revisions" [6] (p. 167).

I would like to contextualize the evolution of transmodern fiction observed by Keen within the framework of this special issue. In line with the theoretical background provided by current scholars 
working on the transmodern paradigm [7-10], I will refer to the definition provided by Ateljevic, who understands transmodernity as "an umbrella term that connotes the emerging socio-cultural, economic, political and philosophical shift" [7] (p. 201) that we are experiencing in the era of globalization. For her, the transmodern is characterized by "a planetary vision in which humans are beginning to realize that we are all [...] connected into one system [...]. Transmodernity is also essentially postpatriarchal in a sense that women's visions and intuitions are to be recognized as indispensable in order to invent together innovative urgent solutions" (p. 203). In addition to this, she explains that we are on the edge of a new relational consciousness that can lead to "the willingness to accept contradicting realities and multicultural perspectives" (p. 213). What this scholar highlights is that, while many different labels are describing this global shift in consciousness, economics, politics, and human relations, all of them signpost similar aspirations for inclusivity, variety, partnership, sustainability, human rights, and the rights of nature. As has been argued by Ghisi [11] and Ateljevic [7], in the transmodern era, humans are becoming more aware of the way "mutual interdependency grows", and how "the hierarchies between different cultures [have started to] dismantle" [7] (p. 203). In addition, for Dussel, the driving force of transmodernity is the intercultural dialogue [8], which provides the transmodern with an enormous potentiality to "articulate a critical cosmopolitanism beyond nationalism and colonialism" [7] (p. 204).

In an era when the new master-narrative appears to be globalization [12] (p. 5), a different interpretive framework for the world is deemed necessary: one that reveals the inter-connectedness of identity, history, memory, and culture while avoiding totalizing practices, and one that connects local descriptions of particular historical and geographical situations with their cross-cultural implications. These new worldviews influence the way fiction is produced and conceived; for example, in today's literary realm, there appears to be a refreshed commitment with history. Contemporary writers still demonstrate an impulse to blur the lines between fiction and reality. However, when historical elements are introduced in fictional works, the main aim is to look for alternative versions of history by underlining the objectivity of the sources included in the fictional artefact without highlighting any discourse artificiality, as happened in Postmodernism. Moreover, emotions play a key role in our recent literature due to the authors' interest in portraying human beings as essentially related to each other. Multidirectional views of human relationships in which our lives, (hi)stories and affects transcend periods of time, connecting us through similar experiences of migration, trauma, and/or conflict [13], are thus promoted. In the case of those narratives representing historical episodes of war and conflict, transmodern fiction may respond in a more creative way than previous narrative modes by making visible the intertwined connections between the global and the local as well as the influence of economic, socio-cultural, and political factors in the course of geopolitical events; questioning the multidirectional and transnational links that influence the citizens' lives; addressing such complex issues as exile and migration through the literary imagination; and giving a voice to vulnerable and silenced victims of worldwide conflicts.

Focusing on the marginal and silenced experiences that occurred during the Second World War, the Nazi occupation of the Channel Islands deserves pride of place as a quite limited number of writers and critics have drawn on this side of British history. However, North American writer Libby Cone has gone a step further with the publication of War on the Margins in 2008 [14], a historical novel set on Jersey during the German occupation and whose main character, Marlene Zimmer, leads the readers to discover a good range of minor stories of war and survival during the Second World War. Above all, this novel shows the female characters' fight against injustice and their struggle for pacifism from such marginal perspectives as those of female members of the French resistance, Jewish and lesbian artists, and Jewish women concealed during the occupation together with those of British citizens, communists, deserters, bystanders, collaborators, and even Nazi soldiers and officers.

Drawing from Rodríguez Magda's distinction between "narratives of celebration" — those that restate the prevailing discourse and hegemonize it-and "narratives of the limit" - those that contemplate what has not been conceptualized yet [15] — the main claim behind this article is that 
liminality is a general recourse in transmodern fiction, but in Cone's War on the Margins, it also acts as a fruitful strategy to represent female communal bonds as promoters of empathy, resilience, and resistance. Firstly, this study will demonstrate how liminality works at the levels of plot, form, genre, and ethics. Moreover, it will identify some of the specific features characterizing transmodern war narratives, such as the blurring of spatial and time dimensions, the crash of local and international boundaries, the recreation of ethical dilemmas, the development of a transcultural consciousness, and the interweaving of historical, literary, and metahistorical discourses. Then, the female bonds in the narrative will be examined in order to prove that War on the Margins relies on the idea of female solidarity and love when it comes to finding resilient attitudes to confront war. Finally, this article will demonstrate that Cone uses these liminal features to voice the difficult experiences that diverse types of women endured during the Second World War, which can echo similar conflictive situations of other women and minority groups in our transmodern era.

\section{Liminality at War}

The concept of liminality was established by ethnologist van Gennep in his pioneering work The Rites of Passage, in which he defined it as a state of in between-ness experienced during religious and cultural rites [16]. With the passing of time, Turner used this notion to allude to some subjects' ambiguous personality. He pointed out that "this condition and these persons elude or slip through the network of classifications that normally locate states and positions in cultural space" [17] (p. 95). Following Sharma's study of this concept [18], other critics like Shields [19] used this notion to define places in which the social order becomes blurred: "the best locations to discover how cultures present themselves, how they interact with each other, how they influence each other and how one culture dominates the other" [18] (p. 110). In line with Freud's theories on the phases of unconsciousness, pre-consciousness, and consciousness, "the stage of liminality [also] helps to examine one's own self in comparison to others and thus provides the opportunity to see the potentiality of an ego which can remain hidden otherwise. [...] It can create sublimating discourse which is possible at borderlines" [18] (p. 110). The psychoanalytical interpretation on the possibility of these borderlines was further fostered by Kristeva when she claimed that liminality, or the person in that state, tends to ask oneself "'Where am I?' instead of 'Who am I?' For the space that engrosses the deject, the excluded, is never one, nor homogeneous, nor totalizable, but essentially divisible, foldable, and catastrophic" [20] (p. 8). Thus, she spread the notion of liminality as an ambiguous and open space, conceived as "a period of transition during which the normal limits of thought, self-understanding and behaviors are relaxed, opening the way to something new" [18] (p. 112). Cultural critics like Deleuze and Guattari [21] and Bhabba [22] made posterior use of this notion to define the interdependence across cultures and the subordination of marginal cultures by the dominant ones.

More specifically, since the turn of the century, many literary critics have drawn on similar theories of liminality in order to point out the emergence of liminal narratives, defined as those that blur the boundaries between fact and fiction, history, legal testimony, psychoanalysis, and theory [23] (p. 14). As I have said previously, Gilmore has claimed that these limit-case narratives "do not seek to provide universal versions of history, or claim to express universal truths, [... as] limit-cases are more concerned with the relation between history and individual stories. These [...] writings provide readers with versions of history that had previously been neglected on the grounds of lack of objectivity and reliability" [24] (p. 230). In fact, Gilmore believes that the hybridity present in these liminal narratives should be understood as an effect of "trauma's centrality to contemporary self-representation" [23] (p. 3). They are the product of the paradoxes resulting from the conflict created when the representation of the self and trauma overlap (p. 19). More recently, Ganteau and Onega have argued that "the complex modal and generic destabilisation that has materialised in the upsurge of a plethora of new hybrid forms reinforces Laub and Podell's contention about the birth of a new art of trauma in the late twentieth century [25], characterised by dialogism, [and] indirection" [26] (p. 5). Such liminal writings have emerged as a response to the uncertainties of a multidirectional 
and transcultural age that has been unavoidably marked by, and is still responding to, some of the darkest episodes of our latest history - the World Wars, the Holocaust, international cases of massive genocide, substantial migratory movements, and international terrorism. Therefore, many of these liminal narratives may be said to have been configured around the concept of trauma and the need to voice collective and individual traumatic experiences as well as to provide a healing mechanism for the transformation of these traumatic experiences into narratives [27-29]. The traditional distinction between literature, testimony, and autobiography has been blurred, and these contradictions have given way to new features present in these liminal narratives. Some trauma literary critics have listed these main characteristics: temporal disruption, belated plots and departure from chronological time, the raising of ethical questions, the presence of motifs that focus on the traumatic processes undergone by the characters, and the blurring of the identities of authors and narrators and the frontiers between fictional and autobiographical elements [27] (pp. 88-116).

In keeping with this, some of these liminal traits could also be found in those transmodern narratives that are at stake in this special issue. Endorsing Rodríguez Magda's distinction between "narratives of celebration"-which "reiterate an accepted topic, [and will] complete the nuances of the dominant discourse until making it hegemonic, even when using elements previously considered as transgressive or innovative" —and "narratives of the limit" — which "struggle to think what has not been conceptualised yet, to say what still has no name; they tear away their old armour in order to explore bare-skinned a landscape still unknown" [15] — her second category in this transmodern classification would find an equivalent in the liminal writings aforementioned. Liminality thus may be said to frame many current transmodern writings in their generic hybridity, formal experimentation, the topics and traumatic episodes represented, the types of characters and their ethical dilemmas, and the time and space relationships portrayed. As will be demonstrated, liminality in War on the Margins acquires diverse faces, all of them exploring innovative ways of understanding human relationships during hostile and traumatic times.

\subsection{A Liminal Topic, A Liminal Setting}

War on the Margins deals with the Nazi occupation of the Channel Islands, an event that is almost entirely absent in most British works depicting the Second World War [30] (p. 5); [31] (p. 10). This may be due to the fact that the German occupation of Guernsey, Jersey, Alderney, and Sark in June 1940 is still a controversial issue, since questions of collaboration-regarding British officials who had to execute German jurisdiction on the islands-and the moral dilemmas concerning the civilians-who sometimes kept silent in the eyes of the Nazi soldiers but also, on other occasions, rebelled against them by hiding Jews and saving camp prisoners-usually come to the fore. The fictional representation of this conflict has a long and peculiar history, which originates in Jerrard Tickell's 1951 novel Appointment with Venus and its subsequent film version [32]. Within the British literary context, Tim Binding published Island Madness in 1998 [33], a relevant novel in that it addressed the complex notions of collaboration and resistance that arise when this "liminal space between Britain and mainland Europe" [5] (p. 93) is examined. In 2004, Guy Walters wrote The Occupation addressing the complex relationships between the German officials and the civilians [34], and Peter Lihou published Rachel's Shoe [35] recounting the story of a Jewish camp prisoner who is helped to flee by a Guernsey family three years later. Also, in 2008, Cone published her work, more in the line of the best-selling The Guernsey Literary and Potato-Peel Pie Society [36]. Both novels rely on letters and documentary history to build up the narration and depict the process of reconstructing the history of this marginal episode of the Second World War by counting on metafictional and metahistorical traits. In spite of the different ways of addressing the topic by British and American authors, as it seems that British writers have been more reticent to deal with this intricate historical episode (or when they have done so, they have done it more indirectly than their American counterparts), all these writings would seem to confirm the notion of the Channel Islands as a kind of "no-man's-land" during the occupation. This has been mainly due to their "geographic particularities [which] seemed to sit during the war in a no man's land of 
occupation and neglect that affected the character traits of the peoples involved, and by extension, their leaders" [37] (p. 95), as well as their liminal status throughout history (p. 97).

This aspect is made clear from the opening of Cone's novel. The first chapter starts with Marlene Zimmer reading the first measures against the Jews on the island of Jersey in The Evening Post [14] (p. 7), and the liminal status of the islands and the islanders, half-way between France and Britain, is one of the first thoughts that crosses her mind: "British but with many French cultural ties, finally had the war brought home to their little feudal paradise of beaches and farms" (p. 8). This way, Cone has chosen a setting that favors the transmodern depiction of non-binary identities, blurred spatial frontiers, and the confrontation of local particularities and international processes during war times. In addition to this, War on the Margins illustrates Ghisi's transmodern views that mutual interdependence and the confusion of cultural hierarchies are essential steps to understand our world order [11]. Furthermore, Dussel's idea that the driving force of the transmodern paradigm is the intercultural dialogue [7] (p. 205) is also echoed in Cone's work. In fact, this writer makes explicit these aspects in the geographical and cultural liminal spaces depicted in her novel.

\subsection{Liminal Ethical Positions}

In her chapter on "Collaboration and Resistance" [5], Stewart claims that, while exploring issues related to guilt, responsibility, and victimhood, some contemporary war narratives have drawn on Hilberg's categorization of victim, perpetrator, and bystander, which he developed in relation to the study of the Holocaust (p. 92). In keeping with Hilberg's definition of the category of "bystander" — which he defined by stating that "in the course of the onslaught on European Jewry, some people in the non-Jewish population helped their Jewish neighbors, many more did or obtained something at the expense of other Jews, and countless others watched what had come to pass" [38] (p. 212) - it was initially thought that the notion of the bystander could lead to a more comprehensive understanding of the ambiguous roles of the agents implied in the Holocaust, as well as in other armed conflicts. Nevertheless, historians like Cesarani and Levine have further argued that these three categories have become rigid as they have come to be used as "monolithic blocs" [39] (p. 2).

Applying these ideas to the British situation during the Second World War complicates the boundaries that can be established between collaboration and resistance even more since "mainland Britain was not invaded and its people did not therefore face the perilous moral choices that confronted the citizens of occupied Europe on a daily basis" [5] (p. 93). Godall has studied the little resistance to the Germans witnessed during the occupation of the Channel Islands, concluding that "the situation was very different in other parts of occupied Europe where organized resistance movements fought desperately against the Germans. [...] The official explanations for this lack of resistance ranged from the smallness of the islands [...] to the absence of men of fighting age" [30] (p. 10). Therefore, it might be argued that Cone decided to focus on the one part of the British Isles that was subject to German rule, the Channel Islands_that "liminal space between Britain and mainland Europe" [5] (p. 93)-because it would confront "readers with the question of whether they would have collaborated, resisted or accommodated" in that situation (p. 93). This is another transmodern feature: the desire to place contemporary readers in critical situations of the past to launch a reflection on current geopolitical movements [40] (pp. x-xi).

By creating miscellaneous characters that represent a blurring of boundaries in the definition of their responsibility or degree of collaboration with the Nazi occupiers, Cone goes beyond clear-cut categories of victim, perpetrator, and bystander. For example, Marlene represents a multifaceted, even ironic, evolution in her personal position within the Nazi occupation of the islands. At first, she appears as a bureaucrat, when in Chapter 2 she has to classify her neighbors into Jews and non-Jews. Then, she confronts the dilemma of whether or not she is considered to be Jewish because of her father's roots, as she wonders: "Why did Jersey Jews have to register in the Aliens Office? [...] I don't count, she thought. I only have two Jewish grandparents ... Am I one? Do I have to register?" [14] (p. 13), until she is asked to register by her superiors (p. 21). As the months go by 
and Marlene realizes the real dangers of her new situation as a Jew in Jersey, she becomes a rebel by dropping her Jewish identity card, as well as that of her neighbor, Miss Viner. Finally, in the spring of 1941, she escapes and hides in Suzanne and Lucy's cottage (see Chapter 11). At this stage, Marlene acknowledges her new active and rewarding role as a collaborator with these Jewish women from the French Resistance as she elaborates such thoughts as: "Lucille and Suzanne [...] actually had ideas and acted on them. Even when they were putting themselves in the greatest danger, [...] Marlene inhaled lungfuls of air [...] to fill herself with the energy to fight" (p. 48). Her next position is that of a Jewish victim, as she is forced to leave Suzanne and Lucy's house when they are arrested, and she has to hide in an abandoned farm, together with Peter, until the end of the armed conflict. Therefore, the character of Marlene embodies the different ways in which people were able, or tried, to cope with the fascist regime in Europe in general, and on these islands in particular, as collaborators, bystanders, rebels, and/or victims. This could also point at Dussel's transmodern belief in the need for alternative versions of history that emerge from the experience of dominated groups of people: "trans-modern culture [...] will have a rich pluriversity and would be the fruit of an authentic intercultural dialogue, that would need to be clearly in mind existing asymmetries (to be an 'imperial-core' or part of the semi-peripheral 'central chorus'" [8] (p. 18). In the case of Cone's novel, this is represented by the mélange of ordinary citizens, officers, and soldiers involved in the Second World War. All of them coming from very different backgrounds and representing diverse cultures, social classes, ethnic backgrounds, political views, and/or religions.

In keeping with this, this fluidity of roles can be applied to most of the characters represented in Cone's writing. Readers find examples of British bureaucrats collaborating with Germany, as in the case of Marlene's boss, Mr. Orange, who has to put into action the strict legislation against the Jews, in spite of the moral dilemmas he comes across. Naturalized British citizens are also depicted protecting the prosecuted Jews, like Albert Bedane-the physiotherapist sheltering one of his Jewish neighbors, Mrs. Richardson, and an unknown Russian prisoner in his house. Cone also describes British subjects who secretly fought against the war and were imprisoned as traitors as a result, such as Pauline-Marlene's colleague in the office fighting for the Resistance after falling in love with Dieter, a German deserter. Along with this, the book renders the lives of the Jewish female artists and lovers Claude Cahun and Marcel Moore (Lucy and Suzanne) as active members of the Resistance who encouraged soldiers to rebel against the regime by carrying out several anti-fascist propaganda acts. Furthermore, communist soldiers enslaved in German labor camps have a place in this novel, such as in the case of Peter - a Polish-Jewish communist from the Dombrowski Brigade who, after fighting in the Spanish Civil War, ends up imprisoned in one of the slave camps that the Germans established on the islands until he finds refuge with Marlene. Even the Nazi soldiers are portrayed from a double-sided moral perspective. For example, this is observed in the hotel when they question the morality of their job: "What are we doing to these people? They're just town and country folk like our people in Germany. They're not monsters" [14] (p. 134), or when Otto, the prison guard in charge of Suzanne and Lucy, is portrayed as the perfect example of a bureaucrat applying Nazi rules while showing signs of humanity: "he adhered fairly strictly to the rules, and was always impassive in demeanor, but displayed great solicitude towards his charges. All in all, the best traits for survival in a fascist state" (p. 212). Again, this wide spectrum of characters and their different but linked positions within the Nazi occupation of the islands seem to endorse Rifkin's [41], Jarowksi's [42], and Dussell's [8] transmodern ideas that all humans are somehow interconnected and that "we are in the long end game of including 'the other', 'the alien', 'the unrecognized'" [41] (p. 26). These are in fact the categories mainly represented in Cone's marginal characters.

In addition to this, the end of the novel can be read as the climax in terms of these ethical dilemmas, mainly for Marlene, Lucy, and Suzanne. On the one hand, Marlene is confronted with her moral doubts about the way she behaved with Pauline, as she discovers that Pauline had been imprisoned because of her false report, whereas this girl was in fact helping prisoners like Peter. She feels guilty about this act but she admits that she also did good things, such as destroying Miss Viner's identity card. 
This dichotomy leads her to a state of anxiety and continuous self-punishing attitudes, as she appears to be constantly judging herself: "Am I a good person or a bad person?" [14] (p. 183). Marlene thus embodies the blurring of definite limits between good and evil during war times. However, she finally understands the lack of moral choices that individuals have when confronted with the evils of war and the multifarious reactions to these choices that humans may experience. Pauline is able to forgive her once the war is over but Miss Viner feels devastated because she never knew that the card had been destroyed and went into hiding anyway, which leads Marlene to elaborate as follows: "The war was big, and I am small. I did some good things, and I did some things that I thought were good but were not, but the war did even bigger things, Hitler did bigger things [...]. A lot of it was out of my control [...] I helped people!" (pp. 244-245). Marlene's words show her ultimate acceptance of the liminal moral choices that this war gave way to for those civilians that were implicated in its horrors [26].

On the other hand, Lucy and Suzanne encounter similar feelings of guilt when, in prison, they come to know about the many soldiers who died because of joining the Resistance or declaring themselves as deserters. Lucille wonders: "How many corpses has the Soldier Without a Name [the pseudonym they used to sign their protest acts] got on his conscience?" [14] (p. 233), but Suzanne reminds her that they cannot measure their acts as if they have been living through ordinary times because "in normal times, you do not do things to get other people in trouble [...]. We had to do it in order to fight the Nazis" (p. 233). This is another reflection on the extraordinariness of this war, which ends with the assertion that "this war is not neat and tidy. History is not neat and tidy" (p. 235). In keeping with this idea, as the war is reaching its end and the Germans' defeat becomes clearer, the narrator even makes explicit the fact that "the boundary between prisoners, at least civilian ones, and guards became more blurred" (p. 235). This moral blurring is highlighted throughout the novel, making it evident that, as Stewart put it in her analysis of Island Madness, novels like these seem to "complicate existing depictions of the war, in that they break down the binary opposition of 'us' and 'them'" [5] (pp. 122-123).

In addition to this, Cone has acknowledged her interest in depicting such variety of characters, most of them inspired by real people, so as to recreate the complex position of the Channel Islands and their inhabitants during the conflict:

Marlene is a fictional character; I just needed to add one more character to the list to propel the story along and to develop the theme of marginality. Most of the characters were real people; Marlene, Peter, Mary Drummond, and Pauline Barrett are composites. People really did try to intercept mail from would-be informants. People really were sent to Ravensbrück and killed for hiding escaped slave labourers. There really was a woman, the lover of a German deserter, who barely escaped execution. [43]

Drawing on this, if one looks at the multifarious individual positions within the war and the mélange of ethical dilemmas depicted, it could be determined that there are "no substantial differences between the patterns of behaviour in the occupied Channel Islands and what happened in other European countries of mainland Europe" [5] (p. 104) during the Second World War, just as there may be no great differences between these fuzzy moral positions and those encountered in other conflicts. As a transmodern war novel, War on the Margins seems to foster a multidirectional model of connecting war experiences and memories_of understanding multidirectional memory as a "multilayered" and "transversal" memory which cuts "across genres, national contexts, periods, and cultural traditions", and which, in spite of possessing a strong collective and historical dimension, is never separated from individual stories [44] (pp. 14-18). This is observed in some repetitive Marlene's thoughts, fostering the connection between her own war experiences and those undergone by her contemporaries in the mainland: "Somewhere in England a late-twentysomething woman like herself was lying in a cellar or a bomb shelter, thinking the same thing" [14] (p. 119). This narrative advocates that the local and individual dilemmas faced by these islanders have global and collective implications when it comes to understanding the liminality of ethics and morality during war times. 


\subsection{Liminal Genres}

The third area of liminality has to do with the generic hybridity displayed, which would define it as an example of Gilmore's liminal narratives. The novel has recourse to a good range of official archives, from the official measures against the Jews to the newspaper articles in the Evening Post and official letters. For instance, readers can find the exchange of letters between Mr. Davidson and the Attorney General concerning the closing of his business in Chapter 5, or the letter of a woman asking if she should be considered as a Jew in Chapter 15. There are also several real documents, such as the list of the Jewish inhabitants of the islands that was created by the Aliens Office, which can be read in Chapter 7, or the real list of all the citizens deported and prosecuted, which appears at the end of the novel. All of them are indicated in the novel by the use of a different typeface, and they are intermingled within the flow of the main storyline, usually appearing in separate short chapters. As the author explained [45], the Jersey Heritage Trust was very helpful in providing her with access to the archives. Together with this, Cone could examine three diaries written by people stuck on Jersey during the occupation, and she could even draw on the British Broadcasting Corporation and German Overseas Radio broadcasts. In fact, the radio appears as a guiding thread connecting different events and characters across the novel. This again fosters a transmodern view of humanity as essentially connected; in this case, through threatening events that could change numerous ordinary lives [40,41]. For example, in Chapter 45 all the characters are connected by listening to the liberation news. On some occasions, the author mixes all these historical documents with the characters' fictionalized reactions to them, as happens in Chapter 31, where the Ninth Order against the Jews precedes Clifford Orange's (the Chief Aliens Officer for Jersey) response to its implementation and he wonders: “Why wouldn't people understand that these registrations had been ordered by the Germans, that an order was an order?" [14] (p. 105). What is more, another use of factual sources concerns the inclusion of the real letters that Lucy and Suzanne exchanged in prison. These letters are inserted within the final sections of the novel and contain deep reflections on the war as well as on these women's possible fates. Moreover, these are beautiful love letters which demonstrate that, even in the face of death, love can find its way. For example, Lucy's lullaby to Suzanne (pp. 222-223) appears as a beautiful declaration of love and optimism when confronting death. Passages like this make evident the optimistic attitude behind such transmodern scholars as Ateljevic [7], Rifkin [41], Pedwell [46], or Held [47]. According to them, the current transnational era, with the new vision of ethics as relational, offers the potentiality "to move beyond traditional dichotomies" [7] (p. 204), demonstrating that "our empathic extension is now exploring previously unexplorable domains is a triumph of the human evolutionary journey" [41] (p. 26).

Moving onto the less historical parts of the narration, Cone makes intertextual allusions to some literary and musical pieces of the time. For example, there is a very compelling reference to Heinrich Heine's well-known poem “The Lorelei" (179) during Lucy's interrogation. Here, the Major asks this woman about her use of the poem to incite young soldiers to desert by changing the original stanza in English- "I think that the waves finally swallowed up the boatman and his boat/That is what the Lorelei did with her singing" [14] (p. 179) —and adapting it for her own political purposes in German: "I think that the waves finally swallowed up the boatman and his boat/That is what Adolf Hitler did with his bellowing" (p. 180). Literature thus acquires a relevant political dimension as an instigator of rebellion, which becomes evident through the abundant presence of poems and literary pieces throughout the novel. References to the song these two women wrote for the Resistance (pp. 36-37), Claude Cahun's poem on "Hell" as an evocation of the maladies of war (p. 78), and Verlaine's "Chanson d'Automne" as the signal that the Resistance was waiting for before the Allied invasion of France (p. 150) demonstrate that, apart from historical evidence, Cone seems to rely on the power of art to provide marginal subjects with a political voice of their own. The author herself acknowledged that Lucy and Suzanne's story "speaks to the hidden power of art and the gifts we receive from those considered marginal by the dominant culture" [43]. 
Yet the general tone of the narrative, even when historical documents are not overtly exposed, is very close to that of historiography by using a language that avoids elaborated literary figures or a very poetic language, as Book Club Forum Reviews pointed out: "The book is told in clean and direct language" [45]. In this sense, Cone's novel shares many aspects with the documentary novel defined by Foley at the end of the 1980s as a novel that is located "near the border between factual discourse and fictive discourse, but it does not propose an eradication of that border." Also, in this case, this blurring of boundaries could be considered as an essential feature of contemporary liminal and trauma narratives. For this critic, the documentary novel "aspires to tell the truth, and it associates this truth with claims to empirical validation," whereas it contains some particular and tangible links to the historical world. This kind of novel "implicitly claims to replicate certain features of actuality in a relatively direct and unmediated fashion; it invokes familiar novelistic conventions, but it requires the reader to accept certain textual elements-characters, incidents, or actual documents-as possessing referents in the world of the reader" [48] (p. 1). All these aspects seem to indicate that the novel's generic liminality responds to Cone's realization that, even though she relies on historical sources in the way documentary fiction usually does, historical facts are not enough when trying to understand traumatic past events; instead, the writer needs to have recourse to a combination of imaginative and non-imaginative sources. This could imply her step forward to help historical and documentary novels advance from the postmodern towards the transmodern paradigm.

Focusing on the evolution of the historical novel, in his essay "From Progress to Catastrophe", Anderson [49], engaging with the work of such Marxist critics as Lukács [50] and Jameson [51], analyses the emergence of this genre with Scott's narratives, its expansion along the 19th century and its recession during the interwar period and the rise of Modernism [51], until he leads readers to the present moment when "the historical novel has become, $[\ldots]$ more widespread than it was even at the height of its classical period in the early 19th century" [49]. This critic emphasizes the revival of this genre during the postmodern era, and sees this phenomenon as paradoxical, mainly according to Jameson's famous statement that Postmodernism should be seen as the age that forgot "how to think historically" [51] (p. ix). This resurgence turned upside down most of the tenets of the classical historical novel [50], and thus the postmodern historical novel tended to randomly mix past and present dimensions as well as use anachronisms, introduce the authorial voice in the main line of the narrative, fictionalize the appearance of leading historical figures, and create alternative endings and historical versions, among other narrative devices. This has been achieved by recounting "military tyranny; race murder; omnipresent surveillance; technological war; and programmed genocide" [49]. However, for Anderson, since Postmodernism, instead of being forgotten, history appears "as a nightmare from which we still cannot wake up". In keeping with Jameson, he also considers that "the postmodern revival [of the historical novel], by throwing verisimilitude to the winds, fabricating periods and outraging probabilities, ought rather to be seen as a desperate attempt to waken us to history, in a time when any real sense of it has gone dead" [49].

In this sense, Cone's narrative may be said to participate of the representational dilemmas surrounding a historical novel that is more obsessed with the rescue of our past than ever. War on the Margins unveils the imprecise borders between "documented public history and the literary", a trait that characterizes many current historical fictions [52] (p. 144). In fact, as has been pointed out, this novel goes beyond the Postmodernist tenets that history and fiction are both discourses. Even though current historical novels like this one draw from the Postmodernist "historical turn" of the 1970s and 1980s, the period when Hutcheon noted the emergence of "historiographic metafiction" (1988) and when Foley defined her famous "documentary novel" (1986), this historical turns seems to be still at work [6] (p. 167). Yet this turn is incorporating invigorated views on the relationship between history, memory, and fiction, which correspond to our transmodern times. Following Manshel's ideas, in the last two decades, a good range of historical novels "has coalesced around a set of increasingly common conventions that demand scholarly attention" [53]. Among the key features he mentions, I would like to highlight those that are more overtly present in War on the Margins: (i) these novels' 
focus on the role of the news and media coverage when decoding and understanding historical events; (ii) these works tend to be influenced by ambivalent politics; and (iii) they "reveal not only the contradictions at the heart of contemporary historical consciousness, but also the crucial blind spots in literary criticism's approach to narratives of the past" [53]. If Jameson criticized the historical novel for appealing to the past by means of "stylistic connotation, a new connotation of 'pastness' and pseudohistorical depth, in which the history of aesthetic styles displaces 'real' history" [51] (pp. 19-20), contemporary historical novels "push toward the boundary between fiction and the 'real' by way of the collision between fictional storylines and nonfictional events" [53], just happens in Cone's narrative. Moreover, when realistic elements are introduced in her novel, this is done to underline the real and deep implications of the events depicted. As Manshel explains,

While postmodern histories approach mediation most often with a sense of curiosity, sublimity, or playfulness, contemporary novelists [...] engage it with what we might call a new sincerity. [...] the New Sincerity in literature is both a rejection and an extension of postmodern styles. Writers of recent historical fiction use many of the same techniques of defamiliarization that mark the postmodern historical novel [... ] in order to pursue a longing for the past with renewed sincerity, effectively re-familiarizing the reader with recent history. [53]

In this sense, Cone succeeds in introducing an array of historical records that can prove the veracity of the (hi)story she wants to tell in her book, just as she includes some of the fictional devices that have been analyzed so far, such as the introduction of a fictional narrator, a polyphony of focalizers, or a non-linear use of chronological conventions. This novel shares, therefore, the spirit of other present-day works addressing the topic of the Second World War, which "take postmodern doubts about the reliability of both memory and documentary evidence as a given; in some respects, the questions about the nature of history that were asked in the 1980s have been reconfigured as recognition of the failures and gaps in memory" [5] (p. 14). It is this acknowledgment of the failure of memory and history when trying to comprehend our traumatic past that has led Cone to exhibit many of the features identified by Keen as characteristic of "New Historical Fiction" [6] (p. 171): the experimentation with form and genre and the disclosure of multiple truths and perspectives on events that had been absorbed by hegemonic discourses. In this way, War on the Margins "participate[s] in historiographic arguments by offering neglected perspectives" and "focusing on places whose history has been ignored" (p. 176). Whereas writers of postmodern historical fiction longed for the representation of the past by making use of irony and self-parody, contemporary writers like Cone show a "a renewed historical sincerity," according to which "the longing for a stable sense of the past [...] is no longer the subject of parody but an object of renewed desire" [53]. Thus, Cone's work does not only question its own truth claims, but shows a transmodern commitment to historical accuracy through the literary imagination. In this transmodern war narrative, both the historical and the literary establish an enriching dialogue. They are not exclusive discourses, but one illuminates the other to offer new insights into past events that had been relegated to the margins of our history and memory. What is more, this dialogue fosters Dussel's belief that the transmodern needs to give voice to those subjects in the margins so as to write alternative versions of history and avoid "a cultural style that tends towards an undifferentiated or empty globalized unity." This way, literary works can promote "a trans-modern pluriversality" [8] (p. 26), which will be discussed in the subsequent section of this article.

\subsection{Liminal Voices and Identitities}

At a formal level, the narrative structure contains some liminal echoes in the sense that the chapters do not follow a strict chronological order; instead, they alternate episodes relating the past lives of some of the protagonists, like Lucy and Suzanne in France, with the chapters containing the archival documents recounting the course of the war, as well as other chapters set and titled according 
to the strategic dates and places in which the war mostly affected the population on the Channel Islands. This way, the organizing force in this narrative is not chronological time but the liminal understanding of time and space that develops in war time, according to which individual lives are marked by the external events that affect the course of the war.

In keeping with this, a polyphony of liminal voices is achieved by the chapters' arrangement in terms of the narrative voice [54]. There is a third-person, external narrator along the narrative but the focalizer changes throughout the novel, turning Marlene, Lucy, Suzanne, and Peter into the eyes through which we see the different episodes of the conflict. This combination of perspectives illustrates that the reconstruction of complex historical episodes cannot be successfully achieved by relying on a single voice, because it needs to incorporate the multifarious voices of the different agents participating in them. Again, this would go in line with the search for plurality and diversity in the margins of history featuring transmodern narratives, as has been argued by Dussel [8] (26).

When it comes to the identities represented, various characters find it difficult to identify themselves. Regarding ethnicity, this is illustrated in the citizens' letters asking whether or not they should consider themselves as Jews and in the key example of Marlene, who constantly asks herself: "Why were Jewish people dangerous"? [14] (p. 143). This can be seen in opposition to the artificial system of classification applied by the German regime, which is depicted as illogical and unnatural when both the officers and the citizens show they are unable to classify themselves and/or their neighbors. In terms of religious identities, something similar happens when many of the characters that are labelled as Jews by the Nazis declare that they do not have any relationship with the Jewish religion but rather with the Church of England, as happens to Mr. Richardson, or even see themselves as atheists, as explained by Lucy and Suzanne: "We grew up in Jewish families, but we did not go to the synagogue. The Nazis do not ask you if you went to synagogue or not" (p. 67). Political identities do not follow any logic either. Peter recounts how many fighters in the Spanish Civil War were "Jews who saw that the first half of the century was not turning in their favour" (p. 83), and thus decided to join the Republican cause, whereas, after that, "France [...] threw the Red Spaniards and Polish Communists into the Gurs and Le Vernet camps" (p. 84), without recognizing their help against the fascist regimes in Europe. This contradictory situation turned many Jewish and/or communist soldiers, like Peter, into stateless and unclassifiable subjects whose political beliefs were dismissed in favor of the dominant political interests of the specific moments of the war. Lastly, when it comes to gender relationships, Lucy and Suzanne (Claude Cahun and Marcel Moore) are the characters that portray the blurring of frontiers most explicitly. In France, these women, who were "welcomed into André Breton's Surrealist sphere" (p. 70), became famous due to their controversial artistic creations and their relationship, breaking down stereotypes that, as narrated in the novel, "posed the awesome threat of the Other; the middle finger stuck up in the face of Authority" (p. 70). Using art as their tool for rebellion, Lucy and Suzanne do not follow any hetero-patriarchal rules, they are lovers and sisters, they appear disguised as men and women, and they do not comply with traditional sexual or gender binaries. Likewise, Marlene and Peter break down all the linguistic, cultural, political, and religious barriers by feeling united through their shared traumatic feelings, as the scene of cleaning themselves in the stream depicts: "She felt stretched and united with him. Everything that had been closed and separated and muffled was open and joined and glistening. They were one clean, sweet-smelling skin" (p. 176).

In opposition to the unnatural view of humanity as binary, which this novel associates with Nazism, Cone's characters exemplify Bauman's [55], Young's [56], and Hall's [57] rejection of those socio-political discourses that have traditionally constructed human identities on the basis of artificial differentiation. Following some of those current thinkers fostering the transmodern view of humanity, the intimate encounters between Cone's characters seem to point at Rifkin's belief in the need of a "global empathy" [40] - a relational consciousness common to the whole of humanity that can help us accept today's contradictory and multicultural realities. This global vision is echoed in these characters' relationships, which go beyond any established assumptions of ethnicity, religion, politics, or gender. 
Gilsenan et al.'s view of transcultural identities as those "multifaceted, fluid identities resulting from diverse cultural encounters" [40] (p. ix) would also be relevant here, mainly in Marlene and Peter's relationship. These characters embody a transcultural experience because against a background of differentiation and hostility-evoked in the previous passage by such damaging adjectives as "separated and muffled"- - their disparate identities are merged into one-as the metaphor of their union in the lake suggests, together with the description of their relationship by employing more constructive adjectives like "open and joined and glistening." Their resulting identities are now multifaceted, hybrid, and fluid; in other words, liminal.

\section{Women at War: Healing and Resistant Bonds}

Some critics, like Scanland, have argued that several Second World War novels written by contemporary female authors highlight "that what matters most in history is often experienced on its margins" [52] (p. 144). These words support the idea that Cone's focus on marginality and liminality is not an isolated phenomenon but a common feature in contemporary historical fiction written by women. This issue has been noticed by Keen, who alludes to the increasing number of women writers of historical fiction in today's literary panorama [6] (p. 170). Generally speaking, this genre has been endorsed by members of minority ethnicities and non-heterosexuals who have re-created their "counterstories" in fictional practices. Yet Keen asserts that women's predominance within this genre has contributed to a "regendering" of historical fiction, which is now considered as a respectable genre for male and female readers and writers (p. 170).

Although the historical novel has always been a form to which women have turned "as a way of making sense of history and their position within it" [58] (p. 54), an evolution can be traced from the historical novels published by women during the first half of the 20th century, whose main aim was to recover the existence of women within hegemonic representations, to those published by the 1980s, which had shifted towards the "lived experiences and perspectives of such women" by exploring "potential expressions of power and agency that had, as yet, not been afforded to them" [58] (p. 43). Moving onto the 1990s, women's historical novels managed to "contest the idea of a single unitary and linear history [ $\ldots$ by underlining] the subjective, fragmentary nature of historical knowledge through rewritings of canonical texts, through multiple or divided narrators, fragmentary or contradictory narratives, and disruptions of linear chronology" [59] (p. 204).

In the case of Second World War narratives, Stewart analyses the increasing interest in this war, demonstrated by such contemporary writers as Sarah Waters, Liz Jensen, and Maureen Duffy, and sees this as part of a "continuing need to come to terms with both the nature of women's participation in the war and the transformation this undoubtedly wrought" [5] (pp. 158-159). If female writers reacting to this war on the spur of the moment, such as Virginia Woolf or Olivia Manning, addressed the effect that the war had on the way individuals conceived themselves within society, contemporary writers, thanks to the belated access to historical and memory sources, appear to be more politically committed in their portrayal of women at war. Mainly focusing on the work of Waters' The Night Watch, Mitchell relates today's female authors' interest in liminal identities to the fact that, rather than evincing patriarchal time, "war is sufficiently disruptive of normative temporalities [ ... that] queer temporalities prevail in wartime" [60] (p. 86). With this claim, she does not only refer to homosexual characters but to "non-normative ways of being" (p. 86). War disrupts most of the mechanisms of ordinary life and female writers point at this extraordinariness by making those non-normative characters come to the surface and reclaim their agency. Therefore, War on the Margins echoes some of the feminist principles present in other historical fiction written by such contemporary British women as MacLeod in Unexploded (2013), Waters in The Night Watch (2006), or Atkinson in Life after Life (2013), works that foreground "the roles that women played in the war effort on the Home Front and emphasize the particular challenges of continuing to go about everyday life and form relationships under the threat of invasion of bombing" [5] (p. 431). 
Applying these notions to War on the Margins, most of the liminal characters mentioned so far are female, and the same goes for the focalizers. The central role of Marlene throughout the novel, as the main focalizer linking the chapters and the diverse war episodes, constructs a narrative where female voices dominate. This fact aligns Cone with the re-gendering of the historical novel, and it demonstrates her interest in emphasizing the daily experiences of singular women during war times, instead of the hegemonic male versions provided in traditional historical narratives, which normally focus on the difficult lives of male soldiers in the battlefield [61] (p. 141). Cone's vision of women goes beyond the patriarchal depiction of female characters as nurses or dutiful workers, and they acquire more active roles as officers, rebels, escapees, and prisoners. Following Rubinstein's definition [62] (p. 46), if feminist novels are "those narratives that take as their central subject the lives and experiences of women while implicitly acknowledging, if not explicitly critiquing, patriarchal social structures", then Cone's narrative contains a significant feminist message. The singular experiences of some miscellaneous women are the focus of this war narrative against a milieu of fascism and war, which are indeed the patriarchal structures criticized throughout the novel. This is a claim that was initiated by Woolf in her pioneering essay "Three Guineas", where she established a direct connection between patriarchy and war [63]. In fact, this connection is fostered by transmodern critics such as Ateljevic, who emphasizes the "postpatriarchal" nature of transmodernity as an attempt at launching a more comprehensive view of humanity [7] (p. 213). Therefore, the microcosmos depicted by Cone at the end of the novel seems to echo this notion of "postpatriarchy" and promote its positive effects for the reconstruction of society [46] after such traumatic war processes as those depicted here.

Other features that contribute to shaping the feminist message expressed by transmodern female war narratives like Cone's novel may be the metahistorical features previously identified-the inclusion of historical records and the elaboration of a historiographic discourse - which are used to claim for the authenticity of these rebellious women's stories and suggest that these are not isolated examples but ordinary reactions that many women displayed during the Nazi occupation of Britain. Similarly, through Marlene's reflections, the novel points at the establishment of multidirectional and transcultural links connecting the suffering endured by these women with diverse people in different places across Europe. This is observed when she elaborates such profound thoughts as:

With a history book with maps borrowed from Lucille and Suzanne's vast library, she began sorting out the different locations mentioned on the wireless: Tunis, Berlin, Kiev, Singapore. She wanted to put a map of the world on the wall and put pins in locations where war was being waged; she wanted to put a big pin on Jersey. Maybe she should just put a pin in her heart, to locate her on the map of suffering which unfolded almost worldwide. [14] (p. 80)

Here, the female protagonist opens her consciousness to the world and other experiences of suffering, acknowledging that her agony is not unique but is what unites her with other human beings. This way, her transcultural attitude in the face of war reaffirms the humanity that the armed conflict wants to steal from marginal subjects like her. Interestingly, Marlene connects this loss of humanity with the image of people turning into rodents [64]. She realizes that "now humans were living more like rodents, hiding in cellars, eating bits of thrown-away food, scurrying into the darkness" (p. 119), and she is even depicted as part of that animalized society: "She was a non-person, a cipher on a camp bed in the cellar, a mouse scratching and squeaking" (p. 131). Nevertheless, this animalization is not interpreted as an excuse for the female characters to avoid agency. For example, this becomes extremely evident in the final chapters in which Lucy and Suzanne claim for their innocence and freedom in front of the German court, as may be read when Lucy fiercely says to one of the German officers: "You are starving us, deporting us and arresting us" (p. 197), thus asserting their individual agency and overtly fighting for their freedom of speech against the dictatorial forces. By inscribing women into this historical narrative as controlling figures, Cone aligns herself with those contemporary women writers whose historical works are aimed at bringing "to light and celebrate the achievements of women during war time" [5] (p. 419). 
In addition to this, my main contention would be that such female agency is mostly achieved through the supportive bonds among the women. These links help them resist Nazi ideas and rebel against the system, as observed at the end of the narrative when Lucy and Suzanne have been condemned to death but still feel proud of their achievements, showing an attitude impregnated by love that helps them resist the Nazis' hatred: "Lucy tried to tell Suzanne that she hoped Suzanne felt as good about her life's work as she, Lucille did, but the words stuck on her thick tongue and she was content to melt into Suzanne's side, smell her smell, and rob the Nazis of their latest pride" [14] (p. 158). Moreover, these women celebrate their capacity to fight against the war and make a call for peace, as revealed when Verlaine's "Chanson d'Automne" announces the beginning of the German defeat, and they celebrate it by acclaiming their love: "She threw on a wig and coat, kissed Suzanne, and slipped out through the back door" (p. 152).

These calls for peace and solidarity are mostly fulfilled through the acts of communal reunion depicted at the end of the novel. Chapter 72 offers a vivid account of the main characters' gathering on 8 May 1945 (the liberation day). This is recreated in the peaceful realm that Lucy and Suzanne's cottage represents throughout the novel. Their house is portrayed as a harmonious small world where, at first, Lucy, Suzanne, and Marlene could share their scarce belongings and struggle against the common enemy (pp. 123-124), and where all the characters can now reunite after the war:

She opened the jar and held it out to Suzanne, then Marlene. The once-ordinary fragrance was almost too much to bear. Pauline continued to stare straight back. Marlene took a dollop of cream, warmed it in her hands, then took one of Pauline's hands, peeling her grip off the chair arm, and began to smooth it into the rough skin. When she started on the other hand, Pauline leaned back in the chair and looked at Marlene. 'Thank you', she said. (p. 241)

This ordinary act of sharing some skin-cream becomes a symbol of communion, reconciliation, and both physical and spiritual healing, especially for Pauline, who can forgive Marlene. The strengthening of these feminine connections allows Marlene, on the one hand, to feel transculturally united with all the people that have been hurt by the war, as can be read in: "she imagined people all over Jersey, all over the world, hugging or sobbing, standing in ashes and thanking God for all they had or lying face-down and cursing God for all that they had lost" (p. 245). However, she is now capable of finding some sense of belonging in the Jewish identity the war has unexpectedly brought upon her, which she wants to embrace together with Peter (p. 247). This final reunion has a clear gender dimension as it is the women in the narrative that have had an active role in expressing anti-war claims and fighting against the Nazi occupation of the islands. In addition to this, these characters' communal act of healing responds to the transmodern model of interdependent relationships. Cone's characters seem to have reached "a heightened empathic sentiment," which allows them "to affiliate with one another in [a] more interdependent, expanded, and integrated social organism[s]" [41] (p. 24). These characters acquire some "responsibility for" the Others' pain [65] (p. 24). Furthermore, this process is made explicit through the metaphor of sharing the skin-cream, which illustrates that now they "hav[e] the other in one's skin" [66] (p. 115). In accordance with this, by understanding resilience as the ability to recover from or adjust to misfortune and change [67] (p. 4), the resilient attitudes promoted by Cone's novel are mainly achieved through the acts of love, solidarity, and empathy in which the female protagonists are involved. As Cyrulnik has pointed out [68] (p. 156), "the dividing line between love and trauma is often a fine one because we are talking about a critical period in which the subject's personality can be reshaped." The characters in this novel find themselves constantly placed in this blurring line, yet the force of love is more powerful than the miseries they encounter and it gives them the strength to continue resisting the dictatorial rule, as the relationship between Lucy and Suzanne demonstrates: "Suzanne looked thinner, of course, but very strong. She gave Lucy a fleeting smile; more would be frowned upon by the Krauts. Lucy's heart swelled with love" [14] (p. 195). Moreover, the power of love is mirrored in the hybrid union of dissimilar characters represented by Peter and Marlene's rapport, as they have been described as two broken characters who heal their damaged souls by helping each other to overcome their war 
traumas. Marlene breaks into tears when she is aware of the suffering Peter has gone through as a slave in the camps, and this deep empathetic connection fills her heart "with the desire to be kind to him" (p. 173). The same may be said of Peter, who helps Marlene accept her actions towards Pauline and Miss Viner and get rid of her guilty feelings. In Cone's novel, love is depicted as a generator of resilience and empathy, which would support again some of the main tenets of the relational ethics and the ethics of love fostered by transmodern thinkers. As we can read in Kristal's view: "One's resilience is proportional to the capacity to mobilize one's love powers. Love outraged is experienced as anger or hate. Love rendered helpless manifests itself as shame. However, love represents the survivor's self-reintegrating and self-healing powers" [69] (p. 62). Thus, War on the Margins may be said to draw from Levinas' ethics of alterity, according to which, characters display an attitude of responsibility towards the "Other," showing their capacity for empathetic feelings towards that "Other's" suffering [62] and displaying a "disinterested movement going outside the self-enclosed identity and towards" the face of the other [70] (p. 361). Levinasian theories became increasingly relevant when the ethical turn materialized in the field of the humanities in the 1980s, and from that moment onwards a growing number of scholars have revisited this humanist philosophy to position themselves towards "some wider opening, some greater sensibility and a surrender of the same in favour of the other/the infinite, that which is otherwise than being, that which is not here, with correlative notions like vulnerability and disinterestedness" [71] (p. 3). Moreover, under different schools and names - the ethics of love, the ethics of care, relational ethics, or cultural transformation theories - these renewed ethical perspectives seem to agree on the need to open to the "Other" through a refreshed view of empathy as transnational, as "an affective bridge between social and cultural differences and an emotional means of achieving social transformation on an international scale" [46] (p. 21).

More recently, Rothberg's conception of multidirectionality and his notion that we are all implicated subjects in the suffering experienced by those distant "Others" —as evinced when he argues that "we are more than bystanders and something other than direct perpetrators in the violence of global capital. Rather, [...] we are implicated subjects, beneficiaries of a system that generates dispersed and uneven experiences of trauma and wellbeing simultaneously" [13] (p. xv)—have developed pari passu with Rifkin's understanding of human evolution towards a more empathic civilization that needs to include the Other [41] (p. 26). Furthermore, according to LaCapra's notion of empathic unsettlement-the ethical movement that helps the addressees of a traumatic story to put themselves "in the other's position while recognizing the difference of that position and hence not taking the other's place" [72] (p. 78)—the female protagonists of this novel are capable of transcending their suffering and looking at the faces of other liminal characters. They succeed in understanding, without appropriating, their suffering and, thus, they manage to find in it their strength to continue fighting for life and peace. This is wisely illustrated in the very final words of the novel, which again point at the healing union between Marlene, Lucy, Suzanne, Pauline, and Peter:

At night by the fire they all held hands and listened to the wireless [... ]. Of course, they began to hear of those who were coming back, and those who were not. They had to deal with the bitterness of seeing the Bailiff knighted, the Aliens Officer still at his job. Healing would go on and on; for some it would never finish. History, like a wave, had picked them up and deposited them unceremoniously back on the sand; at least there was some comfort in recovering together. [14] (p. 248)

Echoing Dussel's and Gilsenan et al.'s transmodern belief in the multiple possibilities that emerged out of such transcultural encounters as those depicted by Cone, this passage illustrates a group of damaged individuals that may start working through their traumatic experiences by empathetically and multidirectionally sharing their pain with those "Others" who have also lived painful events. Therefore, these aspects suggest that Cone's novel displays a model of cultural encounters based on "an inclusive, rather than exclusive understanding of culture as characterized by differences; it emphasizes the need for groups to identify common ground among cultures," in this case their 
marginal identities and the difficult war experiences, and the need for "the individual to acknowledge the foreign within oneself in order to be able to comprehend others" [40] (p. x).

Furthermore, what makes War on the Margins especially singular in this transmodern and "postpatriarchal" context is that it fosters a sense of collectivity and bonding that partially reminds us of those third-wave feminist scholars [73-75] who endorsed a historicist approach to women's issues by highlighting the need to rewrite history from a feminist perspective as the starting point for a critique of patriarchy. These scholars moved beyond the limitations observed in the second feminist wave, displaying a "self-conscious adoption and adaptation of third world feminism's language and politics of hybridity, [...] and the critiques of essentialism and exclusion" [76] (p. 181). This is an essential aspect illustrated in the novel, as the main features linking the characters are those of hybridity, marginality, and liminality when it comes to defining their gender and sexual roles as well as other identity categories such as race and religion. Cone establishes deep bonds between female characters of very different classes and backgrounds, as can be seen in the final scene where French-Jewish artists belonging to the upper class are intermingled with half-Jewish clerks like Marlene or British civil servants like Pauline.

What is more, this gathering of miscellaneous characters echoes some of the key tenets of today's transnational feminism. Following Gilmore and Marshall [77], transnational engagements of womanhood have become influential mechanisms for fostering larger claims for justice and human rights as well as for providing feminine critiques of such deeply-rooted categories as race and gender. For contemporary feminists, the transnational arena becomes "the intersection of the international and the local. Transnational activism brings feminists [...] to work across national borders, and feminist discourses, such as the definition of women's rights as human rights, travel from the international level where they were first formulated to offer new leverage to local activists" [78] (pp. vii-viii). The transnational may function as an analytical tool to see how global processes of war and migration cross all kinds of borders and affect women's lives. In Cone's work, the Channel Islands become a transnational space that acts as the perfect location to transcend local, national, and international frontiers. European and international powers are fighting for this land but their inhabitants go beyond all kinds of identity labels and turn it into a more global space, where the rights these women defend are not exclusively female but necessary human rights to pursue the transmodern vision of global empathy, peace, justice, and sexual, political, and religious freedom. Strong proof of this is the fact that a man is included in the final female reunion, showing a more open-minded view of what feminism may contribute in our transmodern era: the communion of all human beings regardless of their gender, race, religion, social class, or political ideas. The peaceful message behind this novel could lead us to argue that this war novel ends up resembling a narrative of peace, understanding peace literature as that literature that "create[s] unity in diversity" [79] (p. 9, original emphasis). War on the Margins succeeds in "manipulating differences such as nationalism, racism, religionism, and other 'isms" (p. 18) so that these constructions may finally be revealed as unnatural, particularly in the face of war and adversity.

The external forces of history have brought Cone's marginal characters, coming from very different backgrounds and cultures, back to life after these horrible times and this implicates their destinies with each other's. Moreover, even though Stewart claims that today's war novels usually endorse the belief that "in wartime, thinking about the future is always difficult" [80] (p. 424), this novel ends in a more optimistic way by pointing out that, in spite of the never-ending healing these characters will have to handle, "there is some comfort in recovering together" (my emphasis). This way, Cone's liminal narrative opens more possibilities to communal bonding after the multidirectional forces of history have reunited these marginal subjects. Furthermore, this is mostly achieved by relying on the female characters' capacity for love and resilience. Even though this interpretation of the novel might seem quite optimistic, or even utopian, because of the celebratory tone that closes it, it is my contention that this positive attitude echoes the optimism lying behind transmodernism. Returning to the final words of the novel that have been quoted above, although the characters are aware of their 
need to deal with the traumatic losses inflicted by Nazism, to accept the German traces and peoples that will stay in their land, to assume that the pain generated by the war will be an endless process and to acknowledge that humans sometimes cannot confront the historical and political forces that lead to episodes of trauma and war, there is still a future for these liminal characters, and this future lies on their communal bonding and the "comfort in recovering together" (p. 248). This interdependent recovery from the trauma of war demonstrates that, from a transmodern outlook, the main way of conceiving our plural and diverse damaged societies is through community links as those represented here. This novel does not leave its characters stuck in the traumatic process or in the phases of hate and anger towards the perpetrators, as happened in those literary works highly influenced by the trauma paradigm or responding to the trauma novel model [27]. This work moves a step further by depicting refreshed models of relationships, love, and communal living. Even though these models emerge out of pain, war, and difference, the important issue for transmodern times is to find what bonds human beings and what can point towards new models of relating across a world where such liminal spaces as those created in War on the Margins offer the possibilities to heal together [7,8,11,40-42,46].

\section{Conclusions: Writing and Resisting in the Transmodern (Female) Context}

Taking all these points into account, it is time to return to some of the questions posed at the beginning of this study. It has been demonstrated that liminality works at a variety of levels in the narrative: in the historical conflict represented as well as the time and spatial dimensions recreated; in the moral and ethical dilemmas embodied in the different sub-plots; in the generic hybridity and the formal, structural and narrative choices analyzed; and in the blurred identity categories that can be found throughout its pages. In addition to all these forms of liminality, other features displayed by War on the Margins, and which might be applied to other transmodern war narratives, are: the recreation of blurred spatial and time dimensions where local particularities and international processes collide; the attempt to position contemporary readers in complicated situations of the past and implicate them in ethical dilemmas that could be transposed to our times; the development of a multidirectional and transcultural consciousness, going beyond the definite categories of victim, perpetrator, and bystander, and promoting the fusion of the singular and the plural in armed conflicts; the intertwining of historical and literary discourses together with the presence of metahistorical traits targeted at highlighting the veracity of the singular stories behind the historical background depicted; and the ethical dimension intrinsic to the literary work, usually pointing at the need to develop a relational and global consciousness as a possible solution to interpret our chaotic era.

Furthermore, liminality has proved to be the chief resource to voice the hard experiences that many different women had to endure during the Second World War in general and during the occupation of the Channel Islands in particular, and to point at female bonds as active promoters of resilience and resistance. This liminality has been demonstrated to emanate from the author's ethical task of offering a complex vision of a historical episode where marginal voices and their attempts to contribute to peace processes are represented. In this way, Cone contributes to renewing "historiographic arguments" on processes of war and peace "by offering neglected perspectives" and focusing on places whose history had been disregarded [6] (p. 176). Just as Heilmann and Llewellyn claim that women's historical fiction is still very relevant today "in its multiplicity of literary and historical experiences" and because it is not only concerned with looking backwards but "moving forwards" [3] (p. 11), this novel updates the discussion of the role of women during the Second World War, while it also helps contemporary readers reflect on current conflicts where women still play a minor and more vulnerable role [63] (p. 144). It could be concluded that women's historical narratives in the transmodern era may act as a suitable vehicle to endorse the values of transnational feminism together with the transmodern need to problematize the connection between the individual and the collective, the global and the local, history and memory.

Therefore, the marginal characters, the liminal structure, the entangled plot, and the generic hybridity identified respond to Cone's intention to represent the intricate (hi)story that some marginal 
subjects could survive through sisterhood and justice values. Following Gilsenan et al.'s theories [40], works like Cone's come to confirm the power of literature to explore "transcultural experience and grapple with the challenges it poses to individuals and societies alike. The very act of reading literary texts is potentially a transcultural experience, in that it invites the reader to identify with the perspectives of fictional characters from unfamiliar geographical locations, as well as from a variety of cultural and social backgrounds" (pp. x-xi). Just as has been observed in those episodes when Marlene feels connected to all the humans suffering the consequences of armed conflicts or when Lucy and Suzanne claim for a peaceful world from the prison walls, readers get closer to a marginal historical event, starred by marginal characters living marginal stories of survival. Yet this marginality becomes the center in a novel where we can look at the face of many "Others" to feel the communal and universal values inherent to our own individualities and singularities. This work thus exemplifies the healing value of transmodern war narratives. By narrating a story of openness to and communion with the "Other," War on the Margins forces readers to enter a similar dialectical movement to the one that happens at the textual level, extracting from the fictional universe ethical lessons that can be extrapolated to a society that needs to find new mechanisms to provide racial, social, political, religious, and/or sexual minorities with the visibility that hegemonic forces have denied to them. War on the Margins mirrors how transmodern historical women's narratives make use of both the literary imagination and historical discourses to create liminal spaces where hybrid subjects may renegotiate their fragmented identities, and where solidarity and love find their way to offer some alternatives to war and conflict in our chaotic era.

Funding: The research carried out for the writing of this article has been made possible with the support of a project financed by the Spanish Ministry of Economy, Industry and Competitiveness (MINECO) (code FFI2017-84258-P) in collaboration with the European Regional Development Fund (DGI/ERDF); the University of Zaragoza and Ibercaja (JIUZ-2017-HUM-02); and the Government of Aragón (H03_17R).

Conflicts of Interest: The author declares no conflict of interest.

\section{References and Notes}

1. Hutcheon, L. Poetics of Postmodernism: History, Theory, Fiction; Routledge: New York, NY, USA; London, UK, 1988; ISBN 978-0415007061.

2. Lyotard, J.F. The Postmodern Condition: A Report on Knowledge; Manchester University Press: Manchester, UK, 1984; ISBN 0-7190-1450-6.

3. Heilman, A.; Llewellyn, M. Metafiction and Metahistory in Contemporary Women's Writing; Palgrave Macmillan: Hampshire, UK; New York, NY, USA, 2007; ISBN 978-0230005044.

4. Nelson, L.H. Damages Identities, Narrative Repair; Cornell University Press: Ithaca, NY, USA, 2001; ISBN 978-0801487408.

5. Stewart, V. The Second World War in Contemporary British Fiction: Secret Histories; Edinburgh University Press: Edinburgh, UK, 2011; ISBN 978-0748640997. Stewart pays special attention to such writers as Muriel Spark, Olivia Manning and Penelope Lively.

6. Keen, S. The Historical Turn in British Fiction. In A Concise Companion to Contemporary British Fiction; English, J.F., Ed.; Blackwell: Oxford, UK, 2006; pp. 167-183. ISBN 978-1405120005.

7. Ateljevic, I. Visions of Transmodernity: A New Renaissance of our Human History? Integral Rev. 2013, 9, 200-219.

8. Dussel, E. Transmodernity and Interculturality: An Interpretation from the Perspective of Philosophy of Liberation. 2004. Available online: http://enriquedussel.com/txt/Transmodernity\%20and\% 20Interculturality.pdf (accessed on 17 July 2015).

9. Rodríguez Magda, R.M. Transmodernidad; Anthropos: Barcelona, Spain, 2004; ISBN 978-8416906307.

10. Sendón de León, V. La cuestión transmoderna. Una larva se transforma en mariposa. In La condición transmoderna; Rodríguez Magda, R.M., Ed.; Anthropos: Sankt Augustin, Germany, 2015; Volume 241, pp. 113-132.

11. Ghisi, M.L. The Knowledge Society: A Breahthrough toward Genuine Sustainability; Arunchala Press: Cohin, IN, USA, 2008; ISBN 978-8189658144. 
12. Rodríguez Magda, R.M. Transmodernidad: Un nuevo paradigma. Transmodernity 2011, 1, 1-13.

13. Rothberg, M. Preface: Beyond Tancred and Clorinda-Trauma Studies for Subjects. In The Future of Trauma Theory: Contemporary Literary and Cultural Criticism; Buelens, G., Durrant, S., Eaglestone, R., Eds.; Routledge: London, UK; New York, NY, USA, 2014; pp. xi-xviii. ISBN 978-0415694599.

14. Cone, L. War on the Margins; Duckworth Overlook: London, UK; New York, NY, USA, 2008; ISBN 978-0715639726.

15. Rodríguez Magda, R.M. La encrucijada de la transmodernidad. In Proceedings of the Plenary Lecture at the Conference Transmodern Perspectives on Contemporary Literatures in English, Zaragoza, Spain, 26-28 April 2017.

16. Van Gennep, A. The Rites of Passage; Routledge \& Kegan Paul: London, UK, 1960; ISBN 0-7100-8744-6.

17. Turner, V. The Ritual Process: Structure and Anti-Structure; Aline Publishing: Chicago, IL, USA, 1969; ISBN 978-0801491634.

18. Sharma, M. The Liminality of Contemporary Culture. Bodhi 2013, 6, 109-119. [CrossRef]

19. Shields, R. Places on the Margin: Alternative Geographies of Modernity; Routledge: London, UK, 1991.

20. Kristeva, J. Powers of Horror: An Essay on Abjection; Columbia University Press: New York, NY, USA, 1982; ISBN 0-231-05346-0.

21. Deleuze, G.; Guattari, F. Mil Mesetas: Capitalism y Esquizofrenia; Pre-Textos: Valencia, Spain, 1997; ISBN 8485081951.

22. Bhabha, H. The Location of Culture; Routledge: London, UK, 1994; ISBN 978-0415336390.

23. Gilmore, L. The Limits of Autobiography: Trauma and Testimony; Cornell University Press: Ithaca, NY, USA; London, UK, 2001; ISBN 978-0801486746.

24. Pellicer-Ortín, S. Eva Figes' Writings: A Journey through Trauma; Cambridge Scholars Publishing: Newcastle-upon-Tyne, UK, 2015; ISBN 978-1-4438-8062-6.

25. Laub, D.; Podell, D. Art and Trauma. Int. J. Psycho-Anal. 1995, 76, 991-1005. [CrossRef]They defined this new "art of trauma" as imaginative acts that "arise in one's attempt to 'know' the traumatic events that confront him. [...] Art aids survival (as well as recovery) by widening one's vision and offering alternative perspectives and ways of seeing things" (p. 998).

26. Ganteau, J.M.; Onega, S. Contemporary Trauma Narratives: Liminality and Ethics of Form; Routledge: New York, NY, USA; London, UK, 2014; ISBN 978-1138024496.

27. Luckhurst, R. The Trauma Question; Routledge: London, UK; New York, NY, USA, 2008; ISBN $978-0415402712$. He established a kind of canon of trauma fictions formed by Toni Morrison's Beloved (1987), Margaret Atwood's Cat's Eye (1988), Pat Barker's Regeneration Trilogy (1991-5), Anne Michael's Fugitive Pieces, Binjamin Wilkomirski's Fragments (1996), W. G. Sebald's Austerlitz (2001) and Jonathan Safran Foer' Everything is Illuminated (2002) (p. 87).

28. Caruth, C. Trauma: Explorations in Memory; Johns Hopkins University Press: Baltimore, MD, USA; London, UK, 1995; ISBN 978-0801850073.

29. Whitehead, A. Trauma Fiction; Edinburgh University Press: Edinburgh, UK, 2004; ISBN 978-0748618576.

30. DeCoste, D.M. The Literary Response to the Second World War. In A Companion to the British and Irish Novel: 1945-2000; Shaffer, B.W., Ed.; Blackwell Publishing: Oxford, UK, 2005; pp. 3-20. ISBN 978-1405167451.

31. Godall, P. Writing the Literary History of the Channel Islands. Refereed Papers from the Sixth International Small Island Cultures Conference, Guernsey, UK, June 2010. Available online: http:/ / www.sicri-network. org/ (accessed on 8 January 2017).

32. Tickell, J. Appointment with Venus; Hodder and Stoughton: London, UK, 1951.

33. Binding, T. Island Madness; Picador: London, UK, 1998; ISBN 978-0330350464.

34. Walters, G. The Occupation; Headline Book Publishing: London, UK, 2004; ISBN 978-0755320646.

35. Lihou, P. Rachel's Shoe; Libros International: London, UK, 1998.

36. Shaffer, M.A.; Barrows, A. The Guernsey Literary and Potato-Peel Pie Society; Random House: New York, NY, USA, 2008; ISBN 0385341008.

37. Pérez Rodríguez, E.M. How the Second World War Is Depicted by British Novelists Since 1990; The Edwin Mellen Press: Lewiston, ID, USA, 2012; ISBN 978-0773426153.

38. Hilberg, R. Perpetrators, Victims, Bystanders: The Jewish Catastrophe 1933-1845; Harper Collins Publishers: New York, NY, USA, 1992; ISBN 978-0060995072. 
39. Cesarani, D.; Levine, P.A. "Bystanders" to the Holocaust: A Re-Evaluation; Frank Cass: London, UK, 2002; ISBN 978-0714682433.

40. Gilsenan Nordin, I.; Hansen, J.; Zamorano Llena, C. Transcultural Identities in Contemporary Literature; Rodopi: Amsterdam, The Netherlands; New York, NY, USA, 2013; ISBN 978-9042037359.

41. Rifkin, J. The Empathic Civilization: The Race to Global Consciousness in a World in Crisis; Tarcher: Los Angeles, CA, USA, 2009; ISBN 978-0745641461.

42. Jarowski, J. Synchronicity: The Inner Path of Leadership; Berret Koelher: San Francisco, CA, USA, 1996.

43. Cone, L. Behind the Pen: Libby Cone. Rob around Books. 2009. Available online: http://robaroundbooks. com/2009/07/behind-the-pen-libby-cone-author-of-war-on-the-margins / (accessed on 8 January 2017).

44. Rothberg, M. Multidirectional Memory: Remembering the Holocaust in the Age of Decolonization; Stanford UP: Stanford, CA, USA, 1999; ISBN 978-0804762182.

45. BCF Book Reviews. War on the Margins by Libby Cone. 2010. Available online: https://bcfreviews. wordpress.com/2010/10/19/war-on-the-margins-by-libby-cone/ (accessed on 8 January 2017).

46. Pedwell, C. Affective Relations: The Transnational Politics of Empathy; Palgrave Macmillan: Basingstoke, UK, 2014; ISBN 978-1-137-27525-7.

47. Held, V. The Ethics of Care: Personal, Political, and Global; Oxfird University Press: Oxford, UK; New York, NY, USA, 2006; ISBN 0195180992.

48. Foley, B. Telling the Truth: The Theory and Practice of Documentary Fiction; Cornell University Press: Ithaca, NY, USA; London, UK, 1986; ISBN 978-0801418778.

49. Anderson, P. From Progress to Catastrophe. Lond. Rev. Books 2011, 33, 24-28.

50. Lukács, G. The Historical Novel; Merlin: London, UK, 1962.

51. Jameson, F. Postmodernism, or, the Cultural Logic of Late Capitalism; Duke University Press: Durham, UK, 1991.

52. Scanland, M. The Recuperation of History in British and Irish Fiction. In A Companion to the British and Irish Novel: 1945-2000; Shaffer, B.W., Ed.; Blackwell Publishing: Oxford, UK, 2005; pp. 144-159. ISBN 978-1405167451.

53. Manshel, A. The Rise of the Recent Historical Novel. Post 45. 2017. Available online: http:/ / post45.research. yale.edu/2017/09/the-rise-of-the-recent-historical-novel/ (accessed on 30 October 2018).

54. This can be better understood by drawing from Bakhtin's distinction between the "monologic novel", which is controlled by an objective and authorial voice, and the "polyphonic" novel, which presents the dialogic tensions btetween the narrator's and characters' discourses and provides the reader with multiperspectival and contradictory representations of reality. It is this type of novel that can best represent socio-ideological struggle as it displays what he calls "heteroglossia": A multiplicity of social voices, interrelationships, languages and styles. Bakhtin, M. The Dialogic Imagination: Four Essays; Holquist, M., Ed.; University of Texas Press: Austin, TX, USA, 1981.

55. Bauman, Z. Modernity and the Holocaust; Polity Press: Cambridge, UK; New York, NY, USA, 1989; ISBN 978-0745609300.

56. Young, R.J.C. Colonial Desire: Hybridity in Theory, Culture and Race; Routledge: New York, NY, USA; London, UK, 1995; ISBN 978-0415053747.

57. Hall, S. Representation: Cultural Representations and Signifying Practices; Sage and Open University: London, UK, 1997; ISBN 978-0761954323.

58. Wallace, D. The Woman's Historical Novel: British Women Writers, 1900-2000; Palgrave Macmillan: Basingstoke, UK, 2005; ISBN 978-0230223608.

59. Barlow, J.E. Women's Historical Fiction "After" Feminism; Stellenbosch University, 2014. Available online: http:/ / scholar.sun.ac.za (accessed on 7 January 2017).

60. Mitchell, K. What does it feel to be an anachronism: Queer Time in the Night Watch. In Sarah Waters: Contemporary Critical Perspectives; Mitchell, K., Ed.; Bloomsbury: London, UK, 2013; pp. 84-98. ISBN 978-1441199416.

61. Harders, C. Gender Relations, Violence and Conflict Transformation. In Advancing Conflict Transformation. The Berghof Handbook II; Austin, B., Fischer, M., Giessmann, H.J., Eds.; Barbara Budrich Publishers: Opladen, Geramny; Farmington Hills, MI, USA, 2011; pp. 131-155. Available online: www.berghof-handbook.net (accessed on 15 January 2017).

62. Rubinstein, R. The Feminist Novel in the Wake of Virginia Woolf. In A Companion to the British and Irish Novel: 1945-2000; Shaffer, B.W., Ed.; Blackwell Publishing: Oxford, UK, 2007; pp. 45-64. ISBN 978-1405167451. 
63. Woolf, V. A Room of One's Own and Three Guineas; Vintage: London, UK, 1996; ISBN 978-0099734314.

64. This image could be understood as an intertextual allusion to Maus, a key text playing with the metaphorisation of humans becoming animals during the Holocaust but this time with a woman as the protagonist. Spiegelman, A. The Complete Maus; Penguin: London, UK, 2003; ISBN 978-0141014081.

65. Hutchens, B.C. Levinas: A Guide for the Perplexed; Continuum: New York, NY, USA; London, UK, 2004; ISBN 978-0826472830.

66. Levinas, E. Otherwise than Being or beyond Essence; Nijhoff: The Hague, The Netherlands, 1981; ISBN 978-9024723744.

67. Akhtar, S.; Wrenn, G. The Biopsychosocial Miracle of Human Resilience: An Overview. In The Unbroken Soul: Tragedy, Trauma, and Resilience; Parens, H., Blum, H.P., Akhtar, S., Eds.; Jason Arsonson: Lanham, MD, USA, 2008; pp. 1-20. ISBN 978-0765705884.

68. Cyrulnik, B. Talking of Love: How to Overcome Trauma and Remake Your Life Story; Penguin: London, UK, 2007.

69. Krystal, H. Resilience: Accomodation and Recovery. In The Unbroken Soul: Tragedy, Trauma, and Resilience; Parens, H., Blum, H.P., Akhtar, S., Eds.; Jason Arsonson: Lanham, MD, USA, 2008; pp. 47-64. ISBN 978-0765705884.

70. Onega, S. The Nightmare of History, the Value of Art and the Ethics of Love in Julian Barnes's A History of the World in $10 \frac{1}{2}$ Chapters. In Ethics in Culture the Dissemination of Values through Literature and Other Media; Erll, A., Ed.; Walter de Gruyter: Berlin, Germany; New York, NY, USA, 2008; pp. 355-368. ISBN 978-3110200720.

71. Onega, S.; Ganteau, J.M. Ethics and Trauma in Contemporary British Fiction; Rodopi: Amsterdam, The Netherlands; New York, NY, USA, 2011; ISBN 978-9042033269.

72. LaCapra, D. Writing History, Writing Trauma; The Johns Hopkins University Press: Baltimore, MD, USA; London, UK, 2001; ISBN 978-0801864964.

73. Todd, J. Feminist Literary History; Polity Press: Cambridge, UK, 1988; ISBN 978-0745605142.

74. Showalter, E. A Literature of Their Own: British Women Novelists from Brontë to Lessing; Virago: London, UK, 1988; ISBN 978-0691004761.

75. Waugh, P. Feminine Fictions: Revisiting the Postmodern; Routledge: London, UK; New York, NY, USA, 1989; ISBN 978-0415752398.

76. Showden, C.R. What's political about the new feminisms? Frontiers 2009, 30, 166-198. [CrossRef]

77. Gilmore, L.; Marshall, E. Girls in Crisis: Rescue and Transnational Feminist Autobiographical Resistance. Fem. Stud. 2010, 36, 667-690.

78. Ferree, M.M.; Tripp, A.M. Global Feminism: Transnational Women's Activism, Organizing, and Human Rights; New York University Press: New York, NY, USA; London, UK, 2006; ISBN 978-0814727362.

79. Adolf, A. What does Peace Literature Do? An Introduction to the Genre and its Criticism. Can. J. Peace Confl. Stud. 2010, 42, 9-21.

80. Stewart, V. Second World War in Contemporary Women's Fiction: Revisiting the Home Front. Contemp. Women's Writ. 2015, 9, 416-432. [CrossRef]

(C) 2018 by the author. Licensee MDPI, Basel, Switzerland. This article is an open access article distributed under the terms and conditions of the Creative Commons Attribution (CC BY) license (http://creativecommons.org/licenses/by/4.0/). 